\title{
mRNA profile provides novel insights into stress adaptation in mud crab megalopa, Scylla paramamosain after salinity stress
}

Yin Zhang ${ }^{1,2}$, Qingyang $\mathrm{Wu}^{1,2^{*}}$, Shaobin Fang ${ }^{1,2}$, Shengkang $\mathrm{Li}^{1,2}$, Huaiping Zheng ${ }^{1,2}$, Yueling Zhang ${ }^{1,2}$, Mhd Ikhwanuddin ${ }^{2,3}$ and Hongyu $\mathrm{Ma}^{1,2,3^{*}}$ (I)

\begin{abstract}
Background: Mud crab, Scylla paramamosain, a euryhaline crustacean species, mainly inhabits the Indo-Western Pacific region. Wild mud crab spawn in high-salt condition and the salinity reduced with the growth of the hatching larvae. When the larvae grow up to megalopa, they migrate back to estuaries and coasts in virtue of the flood tide, settle and recruit adult habitats and metamorphose into the crablet stage. Adult crab can even survive in a wide salinity of $0-35$ ppt. To investigate the mRNA profile after salinity stress, S. paramamosain megalopa were exposed to different salinity seawater (low, 14 ppt; control, 25 ppt; high, 39 ppt).

Results: Firstly, from the expression profiles of $\mathrm{Na}+/ \mathrm{K}+/ 2 \mathrm{Cl}$ - cotransporter, chloride channel protein 2, and $A B C$ transporter, it turned out that the $24 \mathrm{~h}$ might be the most influenced duration in the short-term stress. We collected megalopa under different salinity for $24 \mathrm{~h}$ and then submitted to mRNA profiling. Totally, $57.87 \mathrm{~Gb}$ Clean Data were obtained. The comparative genomic analysis detected 342 differentially expressed genes (DEGs). The most significantly DEGs include gamma-butyrobetaine dioxygenase-like, facilitated trehalose transporter Tret1, sodium/ potassium-transporting ATPase subunit alpha, rhodanese 1-like protein, etc. And the significantly enriched pathways were lysine degradation, choline metabolism in cancer, phospholipase D signaling pathway, Fc gamma R-mediated phagocytosis, and sphingolipid signaling pathway. The results indicate that in the short-term salinity stress, the megalopa might regulate some mechanism such as metabolism, immunity responses, osmoregulation to adapt to the alteration of the environment.

Conclusions: This study represents the first genome-wide transcriptome analysis of S. paramamosain megalopa for studying its stress adaption mechanisms under different salinity. The results reveal numbers of genes modified by salinity stress and some important pathways, which will provide valuable resources for discovering the molecular basis of salinity stress adaptation of S. paramamosain larvae and further boost the understanding of the potential molecular mechanisms of salinity stress adaptation for crustacean species.
\end{abstract}

Keywords: Scylla paramamosain, Salinity stress, Differentially expression genes, Stress adaptation

\footnotetext{
*Correspondence: qywu1@stu.edu.cn; mahy@stu.edu.cn

'Guangdong Provincial Key Laboratory of Marine Biotechnology, Institute of

Marine Sciences, Shantou University, 243 Daxue Road, Shantou 515063,

China

Full list of author information is available at the end of the article
}

(c) The Author(s). 2020 Open Access This article is licensed under a Creative Commons Attribution 4.0 International License, which permits use, sharing, adaptation, distribution and reproduction in any medium or format, as long as you give appropriate credit to the original author(s) and the source, provide a link to the Creative Commons licence, and indicate if changes were made. The images or other third party material in this article are included in the article's Creative Commons licence, unless indicated otherwise in a credit line to the material. If material is not included in the article's Creative Commons licence and your intended use is not permitted by statutory regulation or exceeds the permitted use, you will need to obtain permission directly from the copyright holder. To view a copy of this licence, visit http://creativecommons.org/licenses/by/4.0/ The Creative Commons Public Domain Dedication waiver (http://creativecommons.org/publicdomain/zero/1.0/) applies to the data made available in this article, unless otherwise stated in a credit line to the data. 


\section{Background}

Mud crab, Scylla paramamosain is a euryhaline crab which can live in a wide range of salinities and mostly distribute in the Indo-Western Pacific region. It has become a fairly important economic mariculture species and popular seafood in the South-East Asian countries [50]. The mud crab aquaculture has been conducted for more than 100 years in China and over the past three decades throughout the Asia [44] and occupied an increasingly momentous role in Chinese crab species farming industry [55]. However, the production is still insufficient to meet the growing demand of the consumer market, which makes the market price of the crab consistently remaining at a high level. In addition, current mud crab mariculture mainly relies on the wildcaught for seed stock of which supply is finite and unreliable, and the expansion is impeded by the lack of access to hatchery-reared seeds $[44,83]$. Mud crab spends most of its life in brackish, saltwater estuaries or mangrove forests, while mature females move to offshore for spawning and hatching larvae [40]. When the larvae grow up to megalopa, they migrate back to estuaries and coasts in virtue of the flood tide, settle and recruit adult habitats and metamorphose into the crablet stage [12]. Megalopa is considered as one of the most crucial stages along the life of the mud crab due to its long habitats shifting and extensive habitats change, and the survival rate of megalopa stage significantly affects population dynamics [12]. Megalopa also constitute a dominant phase for successful larval rearing in mud crab aquaculture, since mass mortality often happens during this stage [12], which makes it an urgent issue to further promote the development of the mud crab aquaculture industry.

Ambient changes play a considerable role in controlling the abundance and distribution of aquatic habitats, especially the estuarine environment, where is the connection of the marine and fresh environment. The variations in abiotic and biotic factors are recorded to result in metabolic, immunological and physiological alterations and trigger stress to the aquatic animals $[6,27$, $28,79]$. The changes of coastal, estuaries, and the culture environment of mud crab, are led by one of the basic ambient factors, salinity, which impacts physiology of the living organisms [72]. The wild and farmed mud crabs are generally exposed to climate changes, like heavy rain and large-scale water change, which directly vary the salinity of the water. Ambient salinity also can be altered by the sea level rising because of ocean acidification, global warming, and timing and amount changes of freshwater delivery [74]. The mud crab megalopa also are exposed to salinity change during the process of migration. What counts is that the salinity is closely related to osmotic pressure which has conspicuous impacts on growth, survival, immune defenses, and respiratory metabolism of marine crustaceans [9, 10, 67, 73]. Acute salinity alterations may also increase energy utilization for osmoregulation and effect the feed intake leading to poor growth of crabs [3, 60] and induce diseases [64].

Although $S$. paramamosain can survive in a broad range of salinity of $2.6-55.5 \mathrm{ppt}$ [95], abrupt changes in salinity, especially the changes exceeding the species's tolerance, will trigger stress responses. Changes in gene expression have been considered as a dominant component for stress management $[6,49,63,66,90]$. Previous study on crab larvae showed that the survival rate could be significantly affected by acute salinity changes [65]. When ambient salinity changes, the mud crab megalopa might compensate for ion loss or excess via osmoregulation by burning more energy, along with a series of stress-induced adaptions, which was the goal of the present study to uncover the molecular alterations caused by salinity adaptions. In recent years, molecular approaches such as microarray, gene library construction, gene expression profiling, transcriptome analysis, and next-generation sequencing have accelerated the search for genes and genetic pathways that respond to environmental challenges by changing their expression, which provides a basic tool for detection of the molecular mechanisms involved in these responses [77, 90]. Studies have investigated the cellular and molecular responses of osmoregulatory enzymes and ion-transport proteins in crustaceans under drastic and long-term salinity stress [13, 17, 37-39]. However, the molecular responses under different levels of salinity have rarely been reported in S. paramamosain, let alone megalopa. Xu and Liu [90] previously reported transcriptome analysis of adult swimming crab Portunus trituberculatus under salinity stress, revealing the expression patterns under low and high salinity conditions compared with optimal salinity to absorb the salinity stress and recognize osmoregulation-related genes of the swimming crab. Hui et al. [42] performed RNA sequencing of Chinese mitten crab, Eriocheir sinensis megalopa before and after desalination indicated that the megalopa might cause a series of stress-induced genes and pathways under low salinity environment. Few information is gainable related to the alterations in genes expressions related to salinity tolerance in S. paramamosain megalopa. S. paramamosain can provide a good model organism, from the perspective of its representative euryhaline habitat and migration life history as well as its important economic value [82], for future studies on physiological, biochemical and immune gene regulation pathways associated with different environmental variations, and also indicators of salinity changes in the offshore environment.

The $\mathrm{Na}+/ \mathrm{K}+/ 2 \mathrm{Cl}$ - cotransporter $(\mathrm{NKCC})$, an integral membrane protein, functioned in transporting $\mathrm{Na}^{+}, \mathrm{K}^{+}$ 
and $2 \mathrm{Cl}^{-}$into cells and plays an indispensable role in osmotic regulation and cell ionic $[25,26]$. The expression of NKCC is sensitive to salinity, and its transcription level is significantly influenced by salinity in crustaceans $[36,57]$. Chloride channel protein $2(\mathrm{ClC} 2)$ is a ubiquitously expressed chloride channel [78] and can be activated by hypotonic swelling [32]. ABC transporters (ABCs) constitute one of the largest protein families that transport different set of substrates across biological membranes including amino acids, ions, toxic metabolites, sugars, xenobiotics, and polypeptides [16, 41], and play vital roles in protecting organisms from the varied environment [56]. To initially detect the impacts of different salinity on the of $S$. paramamosain megalopa in molecular level, we monitor the time-dependent $(0 \mathrm{~h}, 12$ $\mathrm{h}, 24 \mathrm{~h}, 48 \mathrm{~h}$ and $72 \mathrm{~h}$ ) expressions of $\mathrm{NKCC}, \mathrm{ClC} 2$ and $A B C$ genes in megalopa under different salinity treatments. Herein, according to the expression profile of the three osmoregulation related genes, megalopa under salinity stress after certain time will be subjected to high throughput transcriptome sequencing. The present study attempted to unveil the molecular basis of the stress adaption mechanisms of larvae at crucial developmental stages under high and low salinity stress with a transcriptomic analysis of S. paramamosain megalopa. Given the critical role in raising larvae in aquaculture, understanding the molecular level of environmental tolerance and physiological changes is of great value for its management and potential culture.

\section{Results}

\section{Time-dependent expression in different salinity} treatments

The experiment was carried out setting three levels of salinities, namely 14, 25 and 39 ppt. The salinity of 14 ppt was relatively low salinity (LS) while 39 ppt was high salinity (HS), and $25 \mathrm{ppt}$ was set as control group (CS). To preliminary explore the molecular level alterations of osmoregulation under different salinity and period of exposure time, the expressions of osmoregulation related genes $N K C C, C l C 2$ and $A B C$, which were closely related to the osmotic changes, were detected under low and high salinity after $0 \mathrm{~h}, 12 \mathrm{~h}, 24 \mathrm{~h}, 48 \mathrm{~h}$ and $72 \mathrm{~h}$ (Fig. 1). The osmoregulation related gene NKCC was significantly down-regulated at $24 \mathrm{~h}$ under high salinity. The ion transport-related genes $C l C 2$ and $A B C$ were significantly down-regulated both at $12 \mathrm{~h}$ and $24 \mathrm{~h}$ under high salinity. Surprisingly, genes showed no significant differences after $48 \mathrm{~h}$ and $72 \mathrm{~h}$ under salinity alterations, especially at $48 \mathrm{~h}$ the expressions were nearly the same in the three groups and a little deviation presented at $72 \mathrm{~h}$ between the three levels of salinity treatment. Taken together, we chose to further study the gene expressions of the megalopa under low and high salinity after $24 \mathrm{~h}$, thus the $24 \mathrm{~h}$ treatment samples were collected and subjected to the transcriptome sequencing.

\section{Sequencing and assembly and functional annotation} To detect the effects of different salinity on S. paramamosain megalopa, next-generation sequencing was used to explore the variation of differentially expressed genes. After filtering on raw data, removing adaptor and lowquality reads, $57.87 \mathrm{~Gb}$ Clean Data was obtained from LS, CS and HS group in total using Sequencing By Synthesis (SBS) technic. The minimum of base score Q30 was over $92.79 \%$ (supplementary Table 2). Subsequently, the clean data were subjected to map with the reference genome (unpublished data) with mapping ratio from 75.65 to $79.14 \%$. All transcriptome data are available in the NCBI Short Read Archive (SRA) database under accession SRR10493620, SRR10493619 and SRR10493618 corresponding to the LS, CS and HS group, respectively.

A total of 22,766 genes were successfully annotated by aligning to the databases NR, Swiss-Prot, Pfam, KOG, GO and KEGG. For NR species distribution, 21,961 genes matched known sequence from 448 species. Most genes hits were to Hyalella Azteca (6659 genes, 30.40\%), Cryptotermes secundus (952 genes, 4.35\%), Zootermopsis nevadensis (571 genes, 2.61\%), S. paramamosain (539 genes, 2.46\%), Apostichopus japonicus (477 genes, 2.18\%) (supplementary Fig 1). Besides, 11,092 and 14,907 genes were annotated against the protein databases Swiss-Prot and Pfam, respectively.
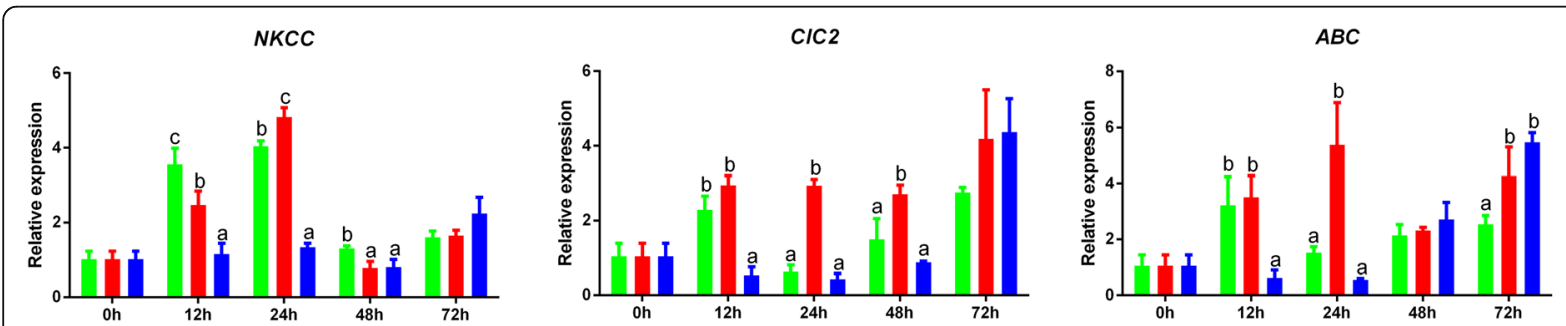

Fig. 1 Relative expressions of genes related to ion transport ( $A B C, C I C 2, N K C C$ ) in Scylla paramamosain megalopa under different salinities after 0 h, 12 h, 24 h, 48 h, and $72 \mathrm{~h}$. LS represents low salinity of 14 ppt, CS represents control group of 25 ppt salinity, HS represents high salinity of 39 ppt. The different letters in the table below represent the significant differences between groups $(p<0.05)$ 
As a consequence, 13,661 genes were annotated in KOG and grouped into 25 KOG classifications (supplementary Fig 2). The largest cluster was "the general function prediction only (R)", indicating the functions of most genes were predicted by informatics methods and has yet to be confirmed by experimentation, and then followed by "signal transduction mechanisms (T)" and "posttranslational modification, protein turnover, chaperones $(\mathrm{O})$ ".

Through the alignment of GO databases, 8468 genes were annotated to 53 terms of GO classification (supplementary Fig 3). For Cellular Component, cell part (2987 genes), cell (2979 genes), membrane, (2440 genes), organelle (1876 genes), membrane part (1431 genes) represented the majority category of this category. Catalytic activity (4009 genes), binding (3743 genes), transporter activity (644 genes), structural molecule activity (305 genes), signal transducer activity (264 genes) represented the majorities of Molecular Function. Cellular process (3756 genes), metabolic process (3515 genes), singleorganism process (2242 genes), biological regulation (1503 genes), localization (1232 genes) represented a high percentage of the Biological Process category, followed by response to stimulus (836 genes) which drew the attention.

Besides, 9877 genes were enriched to 280 KEGG pathways. The pathways including purine metabolism (199 genes), endocytosis (190 genes), lysosome (179 genes), RNA transport (177 genes), protein processing in endoplasmic reticulum (169 genes), phagosome (167 genes), spliceosome (164 genes), ubiquitin mediated proteolysis (160 genes), ribosome (152 genes) and carbon metabolism (134 genes) occupied the Top 10 pathways that enriched the most genes.

\section{Differentially expressed genes and functional annotation}

According to the expressions of the genes in LS, CS, and HS groups, the DEGs were detected in pairwise comparisons. Together, 342 DEGs were spotted, sharing no common DEGs between the three comparisons (Fig. 2). In the comparison of CS vs LS group, 158 DEGs with 87 up-regulated and 71 down-regulated were found (Table 1, supplementary Table 3 ).

In the CS vs LS comparison, the most significantly differentially expressed genes including gamma-butyrobetaine dioxygenase-like (GBDL), facilitated trehalose transporter Tret1 (TRET1), sodium/potassium-transporting ATPase subunit alpha (NKTASa), rhodanese 1-like protein (RHD1-like), proton-coupled folate transporter-like (PCFTL), estrogen sulfotransferase (ESULT), hemocyanin subunit 2 (HcS2), choline transporter-like protein 1 (CTL1), NKCC, vitellogenin-like (VTGL) which were most significantly up-regulated in LS group, and casein kinase II subunit alpha (CK2 $\alpha)$, calponin/ transgelin, zinc finger RNA-binding protein-like (ZFRBL),

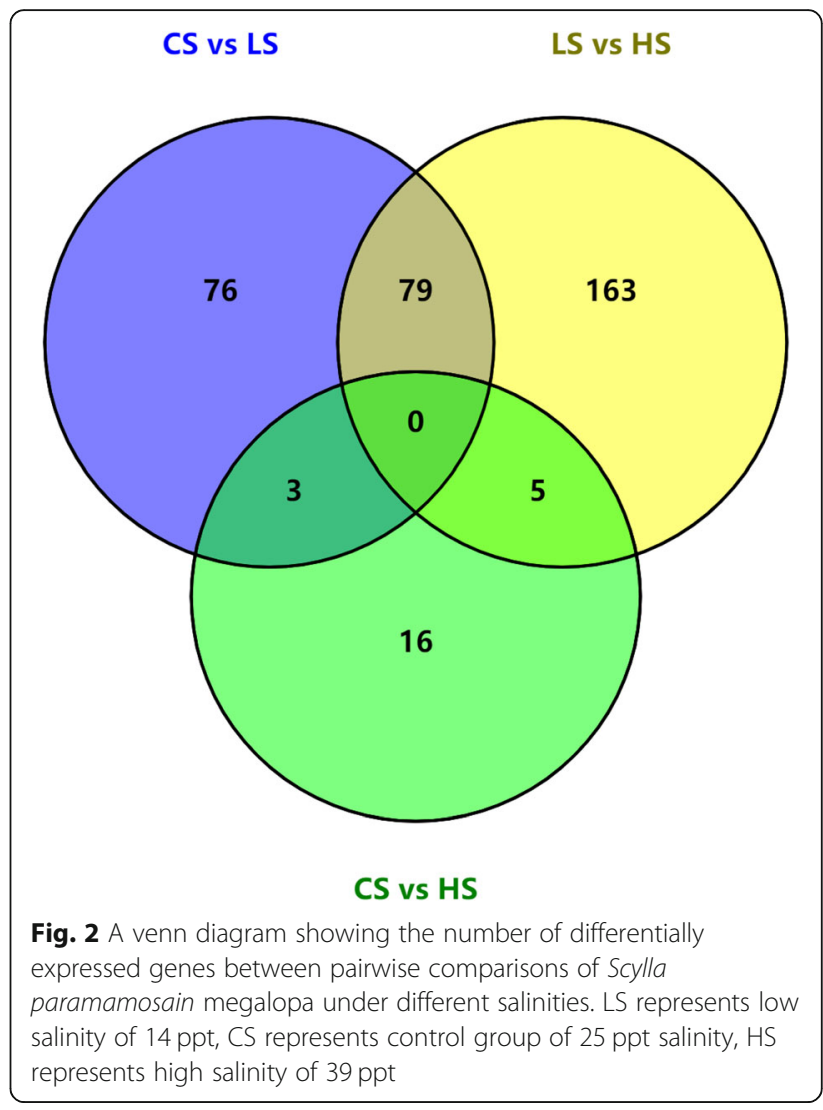

aminopeptidase N-like (APNL), mucin-1, neprilysin-11-like (NEP11L), microtubule-associated protein 1A-like (MAP 1AL) which were most significantly down-regulated in LS group (Table 2; Fig. 3a). The DEGs were further subjected to GO annotations to predict their potential functions, and KEGG enrichment to obtain relevant metabolic pathways. Table 3 shows the GO classifications of the DEGs in comparisons of LS and CS group. Oxidation-reduction process, chloride transport, cell adhesion, tube development and ion transmembrane transport were the most significantly enriched GO function items in the category of Biological Process. In the Cellular Component, integral component of membrane, membrane, extracellular space, plasma membrane and cell junction were the most significant items, while metal ion binding, "oxidoreductase activity, acting on paired donors, with incorporation or reduction of molecular oxygen", iron ion binding, voltage-gated chloride

Table 1 The summary of differentially expressed genes

\begin{tabular}{llll}
\hline Treatment comparisons & DEG Number & Up-regulated & Down-regulated \\
\hline CS vs LS & 158 & 87 & 71 \\
LS vs HS & 247 & 120 & 127 \\
CS vs HS & 24 & 11 & 13 \\
\hline
\end{tabular}

LS Represents low salinity of $14 \mathrm{ppt}$, CS Represents control group of $25 \mathrm{ppt}$ salinity, HS Represents high salinity of $39 \mathrm{ppt}$, DEG Represents differentially expressed gene 
Table 2 Top differentially expressed genes in pairwise comparisons of Scylla paramamosain megalopa

\begin{tabular}{|c|c|c|c|c|}
\hline \#Gene ID & FDR & $\log 2 \mathrm{FC}$ & Regulated & Gene name \\
\hline \multicolumn{5}{|l|}{ CS vs LS } \\
\hline gene.Scaffold1859_g1 & $1.18 \mathrm{E}-26$ & 3.290026 & up & gamma-butyrobetaine dioxygenase-like \\
\hline Scylla_paramamosain_newGene_6838 & 1.47E-16 & 2.989931 & up & gamma-butyrobetaine dioxygenase-like \\
\hline Scylla_paramamosain_newGene_6835 & $5.13 \mathrm{E}-33$ & 2.44134 & up & gamma-butyrobetaine dioxygenase-like \\
\hline Scylla_paramamosain_newGene_33600 & $2.59 \mathrm{E}-10$ & 2.335425 & up & facilitated trehalose transporter Tret1 \\
\hline gene.Scaffold900_g16 & $1.14 \mathrm{E}-19$ & 2.333814 & up & putative defense protein 3 \\
\hline gene.Scaffold728_g5 & $5.51 \mathrm{E}-15$ & 2.212924 & up & $\begin{array}{l}\text { sodium/potassium-transporting ATPase } \\
\text { subunit alpha }\end{array}$ \\
\hline gene.Scaffold1064_g3 & $2.38 \mathrm{E}-38$ & 2.129319 & up & rhodanese 1-like protein \\
\hline Scylla_paramamosain_newGene_6834 & 4.13E-15 & 2.082766 & up & gamma-butyrobetaine dioxygenase-like \\
\hline Scylla_paramamosain_newGene_16509 & 4.33E-07 & 2.01342 & up & $\begin{array}{l}\text { retrovirus-related Pol polyprotein from type-1 } \\
\text { retrotransposable element R1 }\end{array}$ \\
\hline Scylla_paramamosain_newGene_33599 & $4.42 \mathrm{E}-07$ & 1.97739 & up & facilitated trehalose transporter Tret1-like \\
\hline Scylla_paramamosain_newGene_29537 & $2.34 \mathrm{E}-12$ & 1.958022 & up & hypothetical protein DAPPUDRAFT_316225 \\
\hline Scylla_paramamosain_newGene_30171 & $2.00 \mathrm{E}-07$ & 1.881975 & up & proton-coupled folate transporter-like \\
\hline gene.Scaffold3248_g1 & $6.40 \mathrm{E}-06$ & 1.821815 & up & estrogen sulfotransferase \\
\hline Scylla_paramamosain_newGene_1164 & $1.90 \mathrm{E}-10$ & 1.57869 & up & uncharacterized protein LOC108678138 \\
\hline Scylla_paramamosain_newGene_24744 & $2.06 \mathrm{E}-11$ & 1.532331 & up & uncharacterized protein LOC108665683 \\
\hline gene.Scaffold454_g9 & $1.97 \mathrm{E}-05$ & 1.409072 & up & uncharacterized protein LOC108679078 \\
\hline gene.Scaffold2007_g4 & 0.00127 & 1.376571 & up & hemocyanin subunit 2 \\
\hline gene.Scaffold928_g5 & 0.000491 & 1.355006 & up & choline transporter-like protein 1 \\
\hline gene.Scaffold1510_g2 & 2.93E-10 & 1.341927 & up & $\mathrm{Na}+/ \mathrm{K}+/ 2 \mathrm{Cl}$ - cotransporter \\
\hline gene.Scaffold286_g11 & 0.005894 & 1.326881 & up & vitellogenin-like protein \\
\hline Scylla_paramamosain_newGene_8114 & $7.36 \mathrm{E}-35$ & -4.11054 & down & casein kinase II subunit alpha, partial \\
\hline Scylla_paramamosain_newGene_10699 & 4.57E-30 & -3.6122 & down & calponin/transgelin \\
\hline gene.Scaffold1258_g2 & $1.41 \mathrm{E}-07$ & -2.09292 & down & $\begin{array}{l}\text { zinc finger RNA-binding protein-like } \\
\text { isoform X3 }\end{array}$ \\
\hline Scylla_paramamosain_newGene_32270 & $3.42 \mathrm{E}-06$ & -1.88317 & down & hypothetical protein OCBIM_22027343mg, partial \\
\hline Scylla_paramamosain_newGene_19291 & 7.58E-13 & -1.85211 & down & aminopeptidase N-like \\
\hline Scylla_paramamosain_newGene_27140 & 8.06E-06 & -1.81576 & down & mucin-1 \\
\hline gene.Scaffold3610_g1 & 5.05E-09 & -1.66044 & down & neprilysin-11-like \\
\hline gene.Scaffold271_g7 & $2.08 \mathrm{E}-06$ & -1.61464 & down & gamma-butyrobetaine dioxygenase-like \\
\hline Scylla_paramamosain_newGene_40084 & $3.64 \mathrm{E}-06$ & -1.60139 & down & microtubule-associated protein $1 \mathrm{~A}$-like \\
\hline gene.Scaffold132_g13 & 0.00018 & -1.58708 & down & uncharacterized protein APZ42_025850 \\
\hline Scylla_paramamosain_newGene_29679 & 0.000254 & -1.56656 & down & hypothetical protein KP79_PYT22069 \\
\hline Scylla_paramamosain_newGene_36343 & 0.000281 & -1.56571 & down & proton-coupled folate transporter-like \\
\hline Scylla_paramamosain_newGene_21183 & 0.000516 & -1.49135 & down & $\begin{array}{l}\text { conserved Plasmodium membrane protein, } \\
\text { unknown function }\end{array}$ \\
\hline Scylla_paramamosain_newGene_42681 & 8.73E-06 & -1.46576 & down & cuticle protein AM \\
\hline Scylla_paramamosain_newGene_25183 & 0.000497 & -1.4642 & down & reverse transcriptase, partial \\
\hline Scylla_paramamosain_newGene_13981 & 0.001003 & -1.43755 & down & $\begin{array}{l}\text { Succinate dehydrogenase [ubiquinone] } \\
\text { flavoprotein subunit, mitochondrial }\end{array}$ \\
\hline gene.Scaffold1359_g15 & 0.005213 & -1.34713 & down & $\begin{array}{l}\text { (E3-independent) E2 ubiquitin-conjugating } \\
\text { enzyme UBE2O-like isoform X1 }\end{array}$ \\
\hline Scylla_paramamosain_newGene_34432 & 0.004251 & -1.34333 & down & clotting protein precursor, partial \\
\hline Scylla_paramamosain_newGene_25256 & 0.001576 & -1.28034 & down & peritrophin-44-like protein \\
\hline
\end{tabular}


Table 2 Top differentially expressed genes in pairwise comparisons of Scylla paramamosain megalopa (Continued)

\begin{tabular}{|c|c|c|c|c|}
\hline \#Gene ID & FDR & $\log 2 \mathrm{FC}$ & Regulated & Gene name \\
\hline \multicolumn{5}{|l|}{ CS vs HS } \\
\hline gene.Scaffold96_g16 & 0.004113 & 1.046966 & up & projectin \\
\hline gene.Scaffold1291_g1 & 0.002581 & 1.121082 & up & UPF0183 protein CG7083 isoform X2 \\
\hline gene.Scaffold145_g2 & 0.002359 & 1.13704 & up & $\begin{array}{l}\text { ubiA prenyltransferase domain-containing } \\
\text { protein } 1 \text { homolog }\end{array}$ \\
\hline Scylla_paramamosain_newGene_21007 & 0.001607 & 1.164676 & up & $\begin{array}{l}\text { basement membrane-specific heparan sulfate } \\
\text { proteoglycan core protein, partial }\end{array}$ \\
\hline Scylla_paramamosain_newGene_11556 & 0.000132 & 1.396239 & up & multidrug resistance-associated protein 1 isoform $\mathrm{X} 1$ \\
\hline gene.Scaffold1258_g2 & $2.18 \mathrm{E}-08$ & -1.79188 & down & zinc finger RNA-binding protein-like isoform X3 \\
\hline Scylla_paramamosain_newGene_39192 & 0.000382 & -1.27846 & down & gamma-interferon induced thiol reductase GILT3 \\
\hline gene.Scaffold1445_g3 & 0.003801 & -1.18908 & down & structural maintenance of chromosomes protein 2-like \\
\hline gene.Scaffold1241_g1 & 0.002581 & -1.16992 & down & uncharacterized protein LOC108666206 \\
\hline
\end{tabular}

LS Represents low salinity of $14 \mathrm{ppt}$, CS Represents control group of 25 ppt salinity, HS Represents high salinity of $39 \mathrm{ppt}$

a:

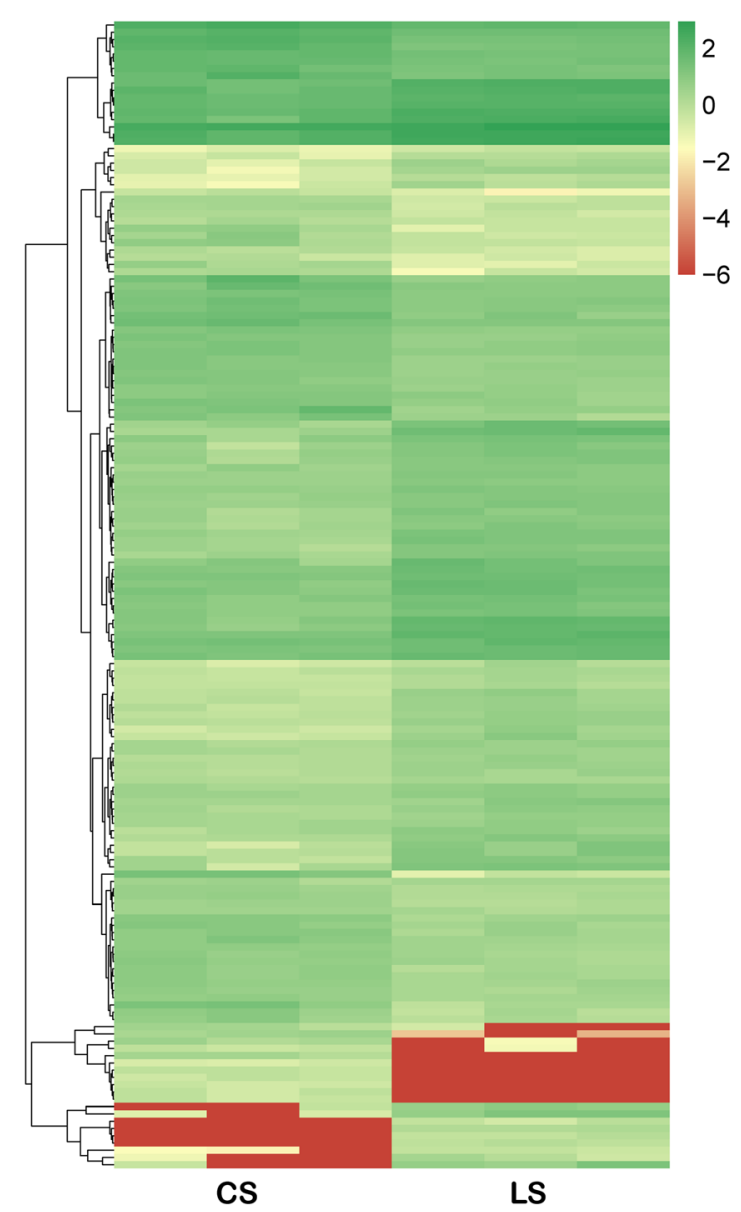

b:

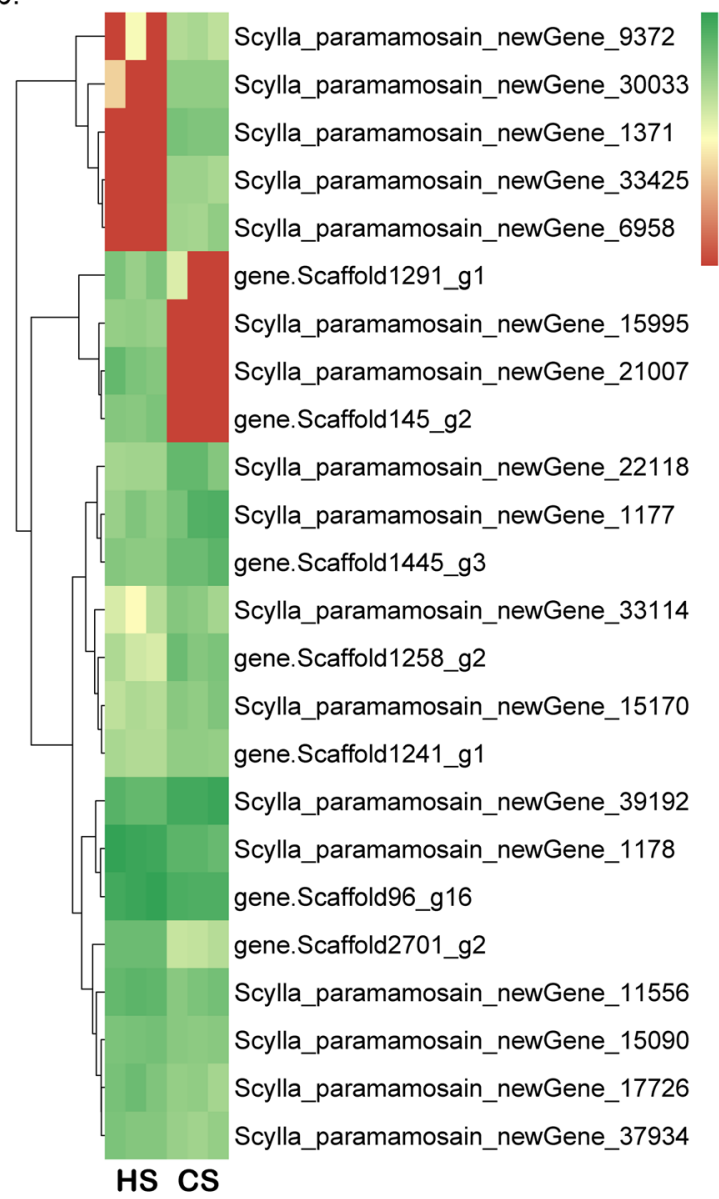

Fig. 3 Heatmap of the differentially expressed genes in the comparison of CS vS LS (a) and CS vs HS (b). LS represents low salinity of 14 ppt, CS represents control group of 25 ppt salinity, HS represents high salinity of $39 \mathrm{ppt}$ 
Table 3 Top 5 GO annotations of the three categories (BP: Biological Process, CC: Cellular Components, MF: Molecular Function) significantly enriched by differentially expressed genes

\begin{tabular}{|c|c|c|c|c|c|c|}
\hline & GO ID & Term & Annotated & Significant & Expected & $P$-value \\
\hline \multicolumn{7}{|c|}{ CS vs LS } \\
\hline $\mathrm{BP}$ & GO:0055114 & oxidation-reduction process & 413 & 4 & 1.73 & 0.00017 \\
\hline $\mathrm{BP}$ & GO:0006821 & chloride transport & 14 & 4 & 0.06 & 0.00047 \\
\hline $\mathrm{BP}$ & GO:0007155 & cell adhesion & 75 & 1 & 0.31 & 0.00089 \\
\hline $\mathrm{BP}$ & GO:0035295 & tube development & 10 & 1 & 0.04 & 0.00584 \\
\hline $\mathrm{BP}$ & GO:0034220 & ion transmembrane transport & 250 & 2 & 1.05 & 0.00624 \\
\hline $\mathrm{CC}$ & GO:0016021 & integral component of membrane & 1230 & 9 & 4.39 & 4.2E-06 \\
\hline $\mathrm{CC}$ & GO:0016020 & membrane & 2483 & 11 & 8.87 & 0.0043 \\
\hline $\mathrm{CC}$ & GO:0005615 & extracellular space & 51 & 1 & 0.18 & 0.0125 \\
\hline $\mathrm{CC}$ & GO:0005886 & plasma membrane & 325 & 3 & 1.16 & 0.0304 \\
\hline $\mathrm{CC}$ & GO:0030054 & cell junction & 66 & 2 & 0.24 & 0.033 \\
\hline MF & GO:0046872 & metal ion binding & 1001 & 4 & 4.91 & 0.00079 \\
\hline MF & GO:0016705 & $\begin{array}{l}\text { oxidoreductase activity, acting on paired donors, } \\
\text { with incorporation or reduction of molecular oxygen }\end{array}$ & 70 & 1 & 0.34 & 0.00107 \\
\hline MF & GO:0005506 & iron ion binding & 50 & 1 & 0.25 & 0.00128 \\
\hline MF & GO:0005247 & voltage-gated chloride channel activity & 4 & 2 & 0.02 & 0.00165 \\
\hline MF & GO:0004175 & endopeptidase activity & 188 & 1 & 0.92 & 0.00337 \\
\hline \multicolumn{7}{|c|}{ CS vs HS } \\
\hline $\mathrm{BP}$ & GO:0051276 & chromosome organization & 156 & 1 & 0.05 & 0.02219 \\
\hline $\mathrm{BP}$ & GO:0006996 & organelle organization & 427 & 1 & 0.15 & 0.48991 \\
\hline $\mathrm{BP}$ & GO:0006793 & phosphorus metabolic process & 815 & 1 & 0.28 & 0.76061 \\
\hline $\mathrm{BP}$ & GO:0009987 & cellular process & 4286 & 2 & 1.49 & 0.8504 \\
\hline $\mathrm{BP}$ & GO:0006796 & phosphate-containing compound metabolic process & 799 & 1 & 0.28 & 0.85274 \\
\hline $\mathrm{CC}$ & GO:0016021 & integral component of membrane & 1230 & 1 & 0.52 & 0.000016 \\
\hline $\mathrm{CC}$ & GO:0016020 & membrane & 2483 & 1 & 1.04 & 0.0039 \\
\hline $\mathrm{CC}$ & GO:0031224 & intrinsic component of membrane & 1235 & 1 & 0.52 & 0.1317 \\
\hline $\mathrm{CC}$ & GO:0044464 & cell part & 2983 & 1 & 1.25 & 0.7094 \\
\hline CC & GO:0005623 & cell & 3005 & 1 & 1.26 & 0.7295 \\
\hline MF & GO:0046872 & metal ion binding & 1001 & 1 & 0.45 & 0.00059 \\
\hline MF & GO:0043169 & cation binding & 1018 & 1 & 0.45 & 0.47576 \\
\hline MF & GO:0004659 & prenyltransferase activity & 10 & 1 & 0 & 0.49112 \\
\hline MF & GO:0016765 & transferase activity, transferring alkyl or aryl (other than methyl) groups & 27 & 1 & 0.01 & 0.58447 \\
\hline MF & GO:0005488 & binding & 3747 & 2 & 1.67 & 0.69304 \\
\hline
\end{tabular}

LS Represents low salinity of 14 ppt, CS Represents control group of 25 ppt salinity, HS Represents high salinity of $39 \mathrm{ppt}$

channel activity and endopeptidase activity were the most significant terms in Molecular Function. The top five significantly enriched KEGG pathways were lysine degradation, choline metabolism in cancer, phospholipase D signaling pathway, Fc gamma Rmediated phagocytosis and sphingolipid signaling pathway (Fig. 4a).

In the comparison of CS vs HS group, 24 DEGs were found, of which 11 were up-regulated and 13 were down-regulated in the HS group (Table 1, supplementary Table 4). The up-regulated genes included multidrug resistance-associated protein 1 isoform X1 (MRP1), ubiA prenyltransferase domain-containing protein 1 homolog, projectin (PRJ) and down-regulated genes such as zinc finger RNA-binding protein-like isoform X3 (ZFRB), structural maintenance of chromosomes protein 2-like (SMC2) and gamma-interferon induced thiol reductase GILT3 (GILT3) under high salinity condition (Table 2; Fig. 3b). The GO annotation only covered four DEGs, resulting in 25 GO terms (Table 3). Phosphorus metabolic process, phosphate-containing compound metabolic process, cellular process, metabolic process 


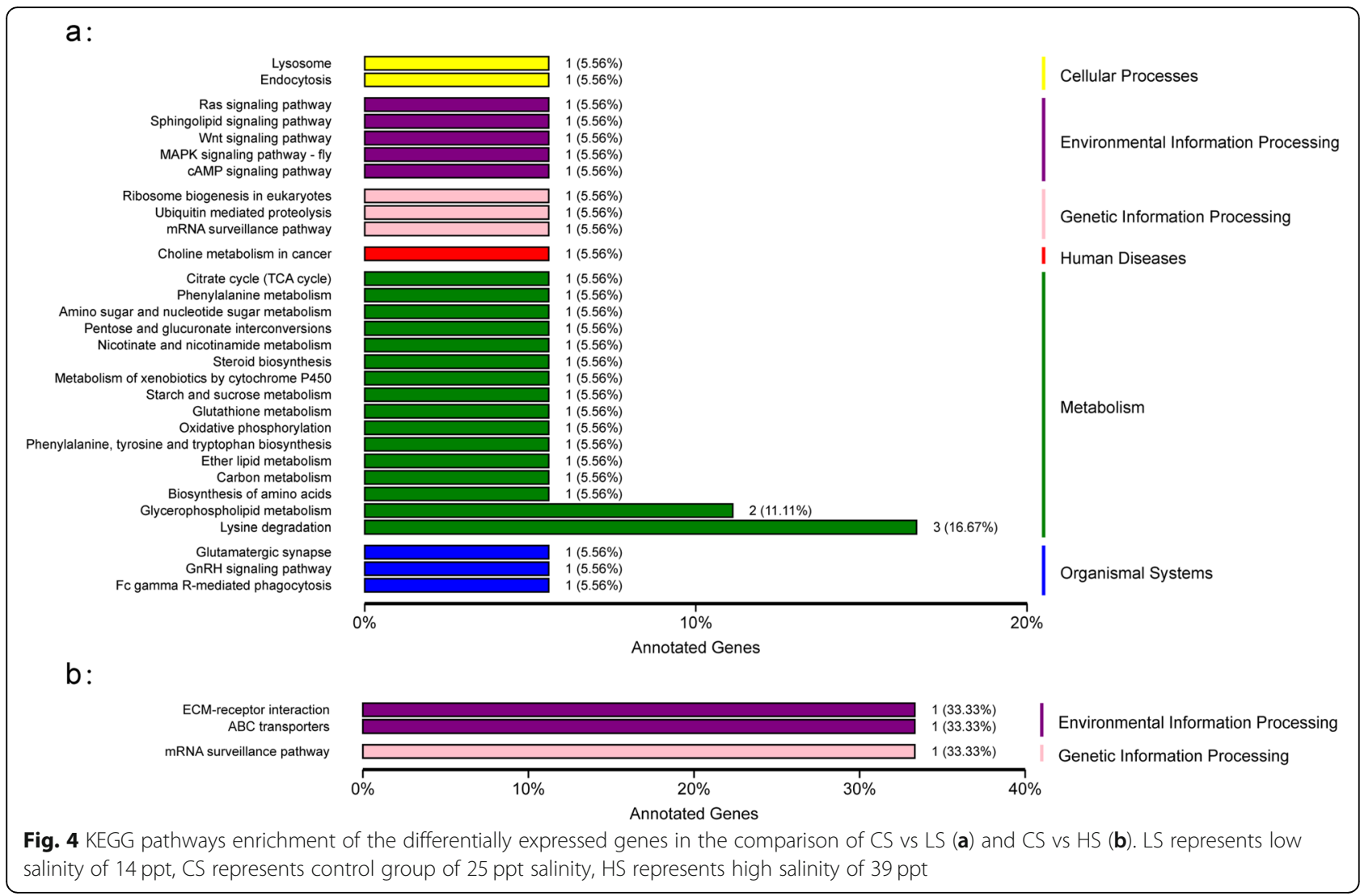

and cellular metabolic process were the most significant GO items in the category of Biological Process. As to the Cellular Components category, the DEGs were enriched for five items including integral component of membrane, membrane, intrinsic component of membrane, membrane part, cellular component. Prenyltransferase activity, transferase activity, transferring alkyl or aryl (other than methyl) groups, heterocyclic compound binding, organic cyclic compound binding and binding were the top five significantly abundant items in Molecular Function. Only 3 pathways were significant in the KEGG pathway enrichment tests, namely ECMreceptor interaction, $\mathrm{ABC}$ transporters and mRNA surveillance pathway (Fig. 4b).

\section{Validation of RNA-seq profile results by qRT-PCR}

To validate the RNA sequencing, nine genes were selected among the Top 50 DEGs in LS and HS groups and quantified using qRT-PCR, namely $A B C$ transporter $(A B C)$, actin (ACTIN), fibrillin-1-like (FBN1), HcS2, innexin 3 (INX3), kelch-like ECH-associated protein 1 (KELCH), mucin-17-like (MUC17), peritrophin-44-like protein (PER44) and serine protease 2 (SP2). The relative expression tendencies of the nine genes were in accordance with the RNA-seq (Fig. 5), validating the results of the mRNA sequencing analysis.

\section{Discussion}

Alterations of osmoregulation and ion transport-related genes under salinity stress during different duration

According to the initial detection, the osmoregulation and ion transport-related genes $\mathrm{NKCC}, \mathrm{ClC} 2$ and $A B C$ were significantly down-regulated under low salinity and high salinity after $24 \mathrm{~h}$. As it's known that NKCC functions in transporting $\mathrm{Na}^{+}, \mathrm{K}^{+}$and $2 \mathrm{Cl}^{-}$into cells and plays an essential role in osmotic regulation and cell ionic $[25,26]$. The transcription level of NKCC is significantly influenced by salinity in crustaceans $[36,57]$. The expression change of $N K C C$ in a euryhaline crab Chasmagnathus granulatus against higher and lower salinity seawater transfer revealed NKCC-driven salt secretion and ion uptake [57]. C1C2 is a ubiquitously expressed chloride channel [78]. It can be activated by hypotonic swelling and may function in cell volume regulation [32]. ABC protein is involved in the regulation of membrane ion channels, especially ATP-sensitive potassium channels [52], and the $A B C$ gene differentially expressed in the present study is most likely to be involved in osmoregulation. The expression of important ion transport-related genes was down-regulated to prevent the high concentration of ions in the environment from penetrating into the body during short-term salinity stress. Besides, the functional processes like 


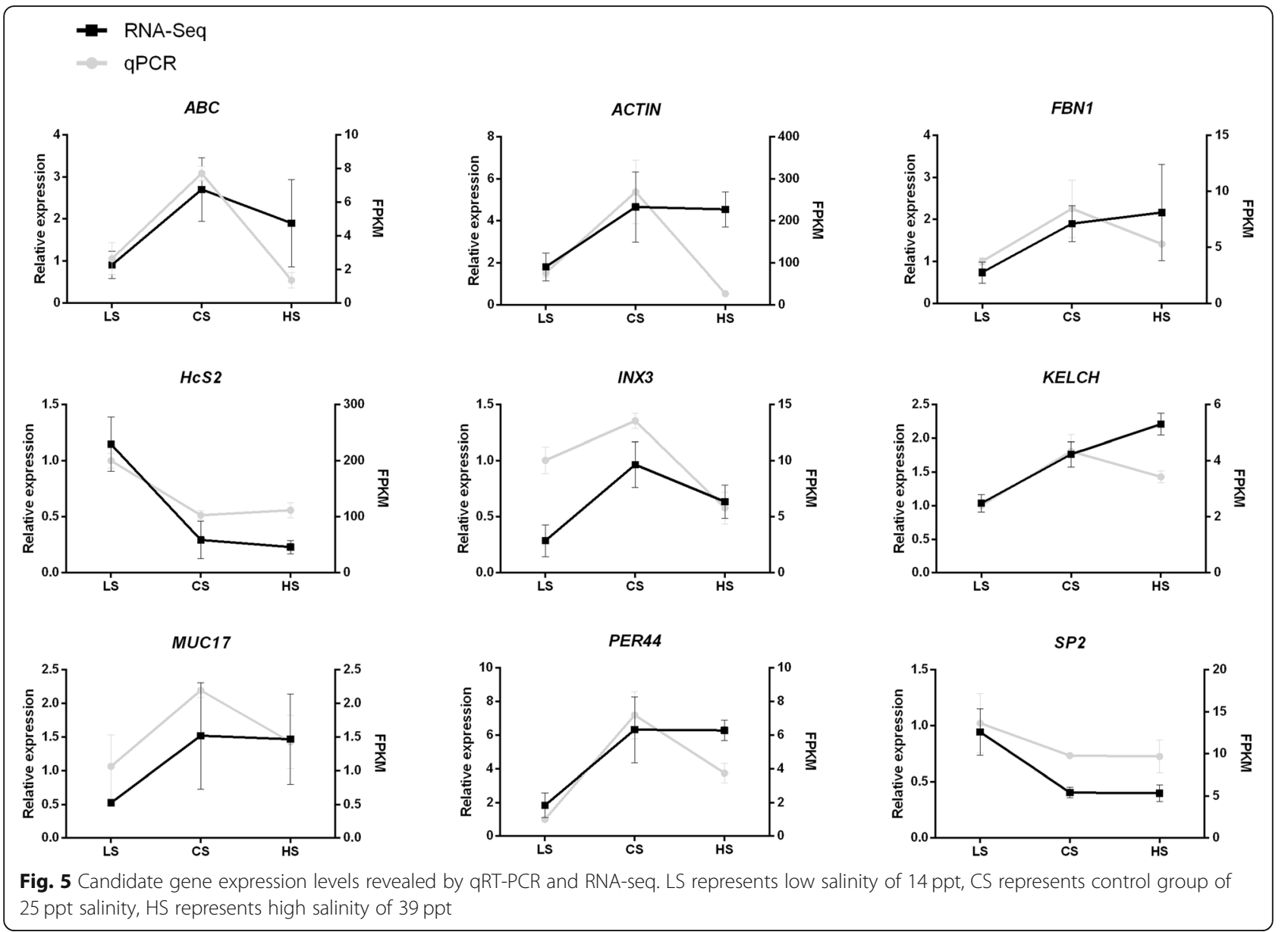

chloride transport, metal ion binding and iron ion binding which were mostly related to ion transport were significantly enriched by DEGs. The results showed that low salinity affects the activity of ion channel [71], which is closely related to the osmotic regulation of $S$. paramamosain.

Dilution or elevation of salinity appears to trigger a classic "stress response" at the level of transcription in S. paramamosain. Strongest differentially expression response in crustaceans tends to occur 1-3 days after salinity transfer [35]. Together with our preliminary detection of osmoregulation related genes under different salinity and period of exposure time, the alterations were obvious after $24 \mathrm{~h}$. Thus, we choose megalopa under salinity stress for $24 \mathrm{~h}$ to identify the genes expressions changes. Hundreds of DEGs were obtained in the present study. Totally, 342 DEGs were obtained including 158 DEGs in the comparison of LS group and CS group, 24 DEGs in HS vs CS and 247 DEGs in LS vs HS. More DEGs were detected in low salinity treatment than that in high salinity, which might be related to the living habitat of megalopa. The observation of fewer DEGs at high salinity suggests that the megalopa could acclimatize themselves to the high salinity of $39 \mathrm{ppt}$ in the current study and might be sensitive to low salinity. Before the zoea metamorphosed to megalopa, they lived in a relatively high salinity environment of which the salinity reached $35 \mathrm{ppt}$ [58]. Among the DEGs, some genes that were most differentially expressed in low or high salinity might play critical roles in adapting the changes of the salinity environment. The differences in gene expressions may mirror the adaptation mechanism of the mud crab megalopa how the larvae survive under salinity condition changes. To identify the responses to changes in salinity at the molecular level, comparisons of gene expressions among the different treatment groups in the present experiment could facilitate the identification of candidate genes underlying response to salinity stress in S. paramamosain larvae.

\section{DEGs under salinity stress indicated stress adaptation of crab larvae}

The most significantly up-regulated genes in LS group includes up-regulated genes related to metabolism (GBDL, PCFT, ESULT, RDL1), osmoregulation (NKTA $S \alpha, C T L 1, N K C C)$ and immunity (TRET1, HcS2, VTGL). 
GBD enzyme is required for carnitine synthesis which is an essential role in fat metabolism [86]. GBDL belongs to the lysine metabolism pathway in the present study. PCFT was regarded as the molecular factor of the carrier-mediated intestinal folate transport system [15, 68]. ESULT was identified as an essential role by adding a sulfate group to estradiol, subsequently it dissolved in the blood and hemolymph to circulate throughout the body $[14,30]$. The RDL proteins have roles in "managing" stress tolerance and in maintenance of redox homeostasis [70, 76]. The knockout of rhodanese genes ( $R D L 1$ and RDL2) made a wine yeast strain Saccharomyces cerevisiae more sensitive to oxidative stress [62]. The up-regulation of GBDL, PCFT, ESULT and RDL1 genes in LS group implied that the megalopa might attempt to adapt the short-term change by adjusting themselves by regulation of homeostasis.

It is no surprise that the osmoregulation related genes including NKTAS $\alpha, C T L 1$ and NKCC were upregulated under the low salinity condition. The $\mathrm{Na}+$ / $\mathrm{K}+$-ATPase is a crucial enzyme to the homeostasis of cell volume, osmotic pressure and the maintenance of electrochemical gradients [2]. CTL1, is involved in supplying choline to certain cell types [61], and the uptake of choline is weakly $\mathrm{Na}^{+}$dependent [24]. What caught our attention was that the most significantly DEGs containing TRET1, HcS2 and VTGL which were directly or indirectly linked to the immunity stress were also up-regulated in LS group. The TRET1 is a trehalose-specific facilitated transporter, and trehalose may be a useful cryoprotective or dehydrating molecule for cells and biological molecules such as proteins and nucleotides [45]. Tret1 expression was also induced by salinity stress in an anhydrobiotic insect [45]. Besides, $\mathrm{HcS} 2$ was up-regulated under low salinity. Hemocyanin is responsible for oxygen transport [18] which might be affected by the salinity change here. Also, hemocyanin plays an important role in non-specific innate immune defense and is an effective immune defense molecule in arthropods [18]. The hemocyanin subunit is the functional group of crustacean immunity. The expression of hemocyanin subunits varies with environmental or nutritional changes in lobsters [7]. It was reported that $\mathrm{HcS} 2$ helped the processed hemocyanin exhibit phenoloxidase activity in crayfish [51]. Vitellogenin is known to be associated with oocyte and embryo development in crab species [91]. Surprisingly, VTGL was up-regulated when the $S$. paramamosain megalopa were exposed to low salinity. We speculated that the up-regulated vitellogenin in the present study might play an immune-relevant role, as previous studies also showed that vitellogenin functioned part in immunity. The first solid evidence of vitellogenin performing an immune-relevant role was observed after vitellogenin was purified from the ovaries of Protochordate amphioxus, Branchiostoma japonicum. It has agglutination activity to chicken, toad and grass carp erythrocytes and antibacterial activity to Gram-negative bacterium, Escherichia coli [94]. After that, vitellogenin from the scallop, Mizuhopecten yessoensis was also shown to have antibacterial activity [87] as well as some other vertebrates and invertebrates [75].

The top significantly down-regulated genes were mainly related to cell differentiation (CK2 $\alpha$, calponin/ transgelin, ZFRBL, MAP $1 A L)$ and immunity (APNL, mucin-1, NEP11L). CK2 is a serine/threonine-selective protein kinase involved in DNA repair, regulation of the circadian rhythm, cell cycle control, and other cellular processes $[1,33]$. CK2 was reported to be implicated in phosphorylation of MAP $1 \mathrm{~B}$, together with MAP 1A, during neuroblastoma cell differentiation [21]. Calponins and transgelins are members of a conservative family of actin related proteins that are widely expressed from yeast to humans [29]. Increased levels of transgelin expression have been associated in cell differentiation and senescence [31]. ZFRBL is responsible for direct, highaffinity binding to messenger RNA (mRNA). The hypotonic environment might reduce the growth from the down-regulation of $C K 2 \alpha$, calponin/transgelin, ZFRB and MAP $1 A L$ which were related to the cell differentiation, thus leading to slowly metamorphosis. The delay of metamorphosis under salinity stress was found in the megalopa of euryhaline crabs Armases miersii [3] and mud crab, Scylla serrata [60]. The deferred growth under inapposite salinity conditions might be out of the alteration of homeostasis responding to the stress [22]. Aminopeptidase $\mathrm{N}(\mathrm{APN})$ is known to selectively decompose amino terminus of proteins or oligopeptides [59]. In animals, APN is most abundant in the brush border membrane of the intestines, accelerating the digestion of absorbed proteins [47]. In the insect midgut, however, APN can act as a receptor for binding to toxin proteins produced by viruses and bacteria [69], which might be its responsibility in the present study. Mucin is the main component of infection-fighting mucous secreted by goblet cells in the intestine [20]. NEP11L was related to neuroendocrine system and might be involved in immune mechanisms [85]. The expression alterations of $A P N L$, mucin- 1 and NEP11L genes here demonstrated that the salinity variation of the environment might cause immunity responses of the larvae.

The most significantly expressed genes in HS group turned out to be up-regulated genes including $M R P 1$, $P R J$ and down-regulated genes such as ZFRB, SMC2 and GILT3, which were mainly implicated in immunity and metabolism. The MRP1 is a major active transporter of glucuronate, glutathione, and sulfate conjugates [53] but 
can also transport unconjugated xenobiotics [93]. It was up-regulated in HS, indicating that high salinity might play as xenobiotics triggering the defense of the body to maintain its homeostasis. PRJ plays a crucial role in stretch activation [81]. It might function in the development of the abdominal stretch of the megalopa whose abdominal will retract under its carapace during this stage. The down-regulated gene ZFRB is responsible in biding mRNA. The main function of GILT is to promote the full expansion of lysosomal degraded proteins by releasing the structural constraints imposed by in-chain and interchain disulfide bonds [5]. SMC proteins are found in almost all organisms. Members of SMC protein family are involved in chromosome coagulation and sister chromatid cohesion and in most cases essential for viability [34].

The most significant DEGs in the low salinity or high salinity were mainly involved in mechanisms such as metabolism, cell differentiation, immunity and osmoregulation. Thus, the megalopa possibly maintain its homeostasis against the environment changes through regulating those DEGs. It indicated that the megalopa as a crab larvae has the ability to protect itself from the short-term salinity stress, which might be closely related to its life history of migration.

\section{Functional enrichment of DEGs showed homeostasis regulation after salinity stress}

The oxidation-reduction process, a GO functional item that is significantly enriched by DEGs in LS group, is crucial for the maintenance of cell homeostasis. Under physiological conditions, cells maintain the oxidationreduction balance through the production and elimination of reactive oxygen /nitrogen species (ROS/RNS) [80]. Normally, homeostasis during redox ensures that cells respond appropriately to both endogenous and exogenous stimuli. However, when the homeostasis of the redox process is disrupted, oxidative stress can lead to abnormal cell death and promote the development of disease [80]. Both exogenous and endogenous contribute to the formation of intracellular ROS/RNS. This study suggested that exposure to salinity stress might activate the oxidationreduction process in S. paramamosain megalopa thus balancing the level of ROS/RNS. Of course, it is also possible that $S$. paramamosain was disturbed in the oxidationreduction process under salinity stress.

This study revealed several important salinity adaptation pathways, which is helpful to understand the molecular basis of osmotic regulation and salinity adaptation in mud crabs. The top five significantly enriched KEGG pathway by DEGs in LS were lysine degradation, choline metabolism in cancer, phospholipase D signaling pathway, Fc gamma R-mediated phagocytosis and sphingolipid signaling pathway, while only three
KEGG pathways (ECM-receptor interaction, ABC transporters and mRNA surveillance pathway) were enriched by the DEGs in HS.

The lysine degradation pathway, enriched most DEGs, was also found to be significantly enriched under chronic low salinity stress in the Pacific white shrimp [11]. It could indirectly affect ion transfer or energy metabolism, promoting "compensation process", which is consistent with the reports of Chinese mitten crab and Pacific white shrimp under salinity stress $[11,54]$. Choline in animal tissues is the main component of the neurotransmitter acetylcholine, and function with inositol as a basic component of lecithin [84]. Besides, phospholipase D catalyzes the hydrolysis of phosphatidylcholine to phospholipid acid and choline. It acts as a regulator of intercellular signaling and metabolic pathways, especially when cells are under stress [8]. Fc gamma R-mediated phagocytosis, immunity-associated pathway, uses actin and microtubule drives to achieve phagocytic formation and intracellular transport between phagocytes and other endocytic compartments [4]. Sphingolipid signaling regulates cellular fitness through a variety of mechanisms. It was shown to be necessary for endocytosis [19, 23]. Sphingolipid signaling may constitute a programmed stress response that occurs before the evolution of apoptosis [48]. Those pathways significantly enriched by DEGs reflected that the megalopa might activate some self-protection system such as ion transfer or energy metabolism, immune response and apoptosis in the short-term salinity stress.

\section{Conclusions}

In conclusion, we analyzed transcriptomic changes in ambient salinity challenges of three different salinities, namely LS, CS and HS. Totally 342 DEGs were found through pairwise comparisons with 158 DEGs in LS and 24 in HS when compared with CS group. The top significantly DEGs in the low and high salinity indicate that the improper salinity environment might cause metabolic disorders. From the most significantly expressed genes in LS and HS including GBDL, PCFT, ESULT, RDL1, NKTAS $\alpha, C T L 1, N K C C$, TRET1, HCS2, VTGL, CK2 $\alpha$, calponin/transgelin, ZFRBL, MAP 1AL, APNL, mucin-1, NEP11L, MRP1, PRJ, ZFRB, SMC2 and GILT3, it indicated that in the short-term salinity changes, the megalopa will regulate some mechanisms such as metabolism, oxidative stress, osmoregulation to adapt the alteration of the environment. Thus, the salinity change might impact the growth by megalopa and cause immunity responses. The top five significantly enriched KEGG pathway by DEGs in LS and HS were mostly related to immunity responses. These pathways and gene expression patterns provide new insights into the 
molecular mechanisms of immune responses and osmotic regulation under salinity stress in crustaceans.

\section{Methods}

\section{Ethics statement}

All experiments were conducted with strict accordance with the recommendations in the Guide for the Care and use of Laboratory Animals of Shantou University and approval of the Institutional Animal Care and Use Ethics Committee of Shantou University. All efforts were made to minimize S. paramamosain suffering.

\section{Sources of megalopa, experimental design and sampling}

The experiment was conducted at Raoping West Coast Biotechnology Co. Ltd., Chaozhou, Guangdong province, China. Females S. paramamosain with full ovarian development (ovarian maturation Stage V) [88] were purchased from local fishermen in May 2019. Crabs were held in $20 \mathrm{~m}^{3}$ cement pond with disinfected seawater (temperature: $25-30{ }^{\circ} \mathrm{C}$; salinity: $26-29 \mathrm{ppt}$ ) and fed once daily in the afternoon $(3: 00 \mathrm{pm})$ with razor clam Sinonovacula constricta at approximately $10 \%$ body weight. Before spawning, the berried crabs were reared individually. When the color of eggs turned to dark grey or black, the berried crab was transferred to a cement pond $(5 \times 4 \times 1.5 \mathrm{~m})$. The newly hatched larvae were cultured at a density of $50-100$ individuals per liter and were fed with rotifer, Brachionus sp., at Zoea I and Zoea II stage. When the larvae metamorphose to Zoea III, the diet was switched to brine shrimp Artemia nauplii. The salinity and water temperature were maintained between 26 and $29 \mathrm{ppt}$, 25 and $30^{\circ} \mathrm{C}$, respectively.

A preliminary experiment was set six levels of salinity, namely $7,14,21,28,35$ and $42 \mathrm{ppt}$ to determine the optimum salinity of the mud crab megalopa. One day after zoea metamorphosed to megalopa, the megalopa with robust vitality were selected out for salinity treatment. The metamorphosis number of the megalopa was recorded when the megalopa begin to metamorphose. After 8 days, the metamorphosis rate of each group was calculated respectively. Based on the metamorphosis rate of megalopa under different salinities in the preliminary experiment, the salinities were set as 14, 25 and $39 \mathrm{ppt}$ with triplicates. One hundred robust megalopa were utilized for each replicate cultured in $50 \mathrm{~L}$ culture tanks. The megalopa were collected according to the timeline at $0,12,24,48$ and $72 \mathrm{~h}$, stored in RNAlater (Vazyme BioTechnologies Co., Ltd., Nanjing, Jiangsu, China) for subsequent RNA extraction. The megalopa were fed adult Artemia in both experiments. The mean temperature was $28 \pm 2{ }^{\circ} \mathrm{C}$ for the experiment.

\section{RNA isolation and sequencing}

Total RNA was extracted from megalopa treated in 14, 25 and 39 ppt salinities for $24 \mathrm{~h}$, respectively. Each treatment was set three replicates and each replicate used eight individuals for RNA isolation using the Trizol kit (Invitrogen, USA) following the manufacturer's instructions. The purity, concentration and integrity of RNA samples are tested using NanoDrop 2000 (Thermo Scientific, Waltham, MA) and Agilent 2100 Bioanalyzer (Agilent, Santa Clara, CA) to ensure qualified samples prior to transcriptome sequencing.

Totally $1 \mu \mathrm{g}$ of qualified RNA (RNA quality score (RQS) 6.0-8.0 and the OD260/280 1.8-2.0) per group was directed at RNA sample preparations. Libraries for sequencing were generated using NEBNext UltraTM RNA Library Prep Kit for Illumina (NEB, USA) according to manufacturer's instructions. Subsequently, each sample attached with index codes to characterize sequences. In brief, mRNAs were purified from total RNA using poly $\mathrm{T}$ oligomer magnetic beads. In NEBNext First-Strand Synthesis Reaction Buffer (5X), bivalent cation is used for cleavage at high temperature. The first strand cDNA was synthesized by random hexamer primers and M-MuLV Reverse Transcriptase. The second strand of cDNA was then synthesized using DNA Polymerase I and RNase $\mathrm{H}$, and the remaining overhangs were converted to blunt end by exonuclease/polymerase. After the 3 'end of DNA fragment was adenylated, the NEBNext adaptor of hairpin loop structure was ligated for hybridization. To preferentially select $240 \mathrm{bp}$ cDNA fragments, library fragments were purified using the AMPure XP system (Beckman Co., Beverly, USA). The USER enzyme (NEB, USA) was added to the cDNA with selected size and adaptor, and PCR was performed with Phusion High-fidelity DNA polymerase after $15 \mathrm{~min}$ at $37^{\circ} \mathrm{C}$ and $5 \mathrm{~min}$ at $95^{\circ} \mathrm{C}$, universal PCR primers and index $(\mathrm{X})$ primers were used for PCR. Finally, the PCR products were purified by AMPure XP system and the quality of the library was evaluated on the Agilent Bioanalyzer 2100 system. According to the manufacturer's suggestion, TruSeq PE Cluster Kit v4-cBot -HS (Illumia) was used to cluster the index-coded samples on the cBot Cluster Generation System. After clustered, library preparations were sequenced on Illumina platform to generate paired-end reads by Biomarker BioTechnologies Co. Ltd., Beijing, China.

\section{Data analysis and functional annotation}

Raw data (raw reads) generated by Sequencing By Synthesis technology in fastq format were first processed by an in house perl scripts which is proprietary by Biomarker BioTechnologies Co. Ltd., Beijing, China. In this step, clean data (clean reads) could be obtained by removing the reads that contained the adaptor or ploy- $\mathrm{N}$ 
and the low-quality reads in the raw data. Meanwhile, the Q20, Q30, GC-content and sequence repetition levels of clean data were calculated. All downstream analyses were based on high quality clean data. These clean reads were subsequently hit to reference genome sequences (unpublished data, the genome is available upon request.). Only reads with maximum one mismatch were further analyzed and annotated against the reference genome. HISAT2 software ([46], http://ccb.jhu.edu/software/hisat2/index.shtml) were used to map with the reference genome.

Gene function was annotated based on the following databases: $\mathrm{Nr}$ (NCBI non-redundant protein sequences, $\mathrm{ftp} / / / \mathrm{ftp}$. ncbi.nih.gov/blast/db/), Swiss-Prot (A manually annotated and reviewed protein sequence database, http://www.uniprot.org/), Pfam (Protein family, http:// pfam.xfam.org/), KOG (The database of Clusters of Protein homology, http://www.ncbi.nlm.nih.gov/KOG/), GO (Gene Ontology, http://www.geneontology.org/) and KEGG (The database of Kyoto Encyclopedia of Genes and Genomes, http://www.genome.jp/kegg/).

\section{Quantification of gene expression levels and differential expression analysis}

Gene expression levels were calculated by fragments per kilobase of transcription per million (FPKM). DESeq2 was used for differential expression analysis between every two groups and provided statistical routines to determine differential expression of digital gene expression data using a model based on negative binomial distribution. The $P$ value was adjusted using methods of Benjamini and Hochberg to control the false discovery rate. Genes with $p$ value less than 0.01 was considered as differentially expressed gene (DEGs). The GO enrichment analysis of DEGs was performed using GOseq R software packages based on the Wallenius non-central hypergeometric distribution [92], which can adjust the gene length bias in DEGs. KEGG [43] is a database resources to understand the advanced features and practical application of biological systems, such as cells, biological and ecological system, the information from the molecular level, especially large-scale genome sequencing of molecular data sets and other highthroughput experimental technologies (http://www.genome.jp/kegg/). We used KOBAS 2.0 [89] to test the statistical enrichment of DEGs in the KEGG pathway.

\section{Quantitative real-time PCR for RNA-seq results validation}

Nine genes were screened out for RNA-seq validation using quantitative real-time PCR (qRT-PCR) with Talent qPCR Premix (SYBR Green) kit (TIANGEN Biotech Co., Ltd., Beijing) according to the manufacturer's instructions. cDNA was produced from $2 \mu \mathrm{g}$ total RNA using FastKing gDNA Dispelling RT Supermix (TIANGEN Biotech Co., Ltd., Beijing). Primers (supplementary Table 1) for qRT-
PCR were designed using the Primer 6.0 Software. qRTPCR was performed in a Mini Option real-time detector (Roche Light Cycle@480). The qRT-PCR reaction solution included $5 \mu$ l Talent qPCR Premix $(2 \times)$ (TIANGEN Biotech Co., Ltd., Beijing), 0.4 $\mu \mathrm{l}$ PCR forward primer $(10 \mu \mathrm{M}), 0.4 \mu \mathrm{l}$ PCR reverse primer $(10 \mu \mathrm{M}), 2.0 \mu \mathrm{l}$ cDNA solution (20 ng), and $2.2 \mu \mathrm{l}$ RNase-free water. The reaction conditions were followed by the recommendation of the instruction. Agarose gel electrophoresis was performed on all amplifiers to determine their size. The expression level of each gene was normalized towards the reference gene (18 s rRNA). The optimized comparative $\mathrm{Ct}\left(2^{-\Delta \Delta \mathrm{Ct}}\right)$ value method was applied here to calculate gene expression levels.

\section{Supplementary information}

Supplementary information accompanies this paper at https://doi.org/10. 1186/s12864-020-06965-5.

Additional file 1: Supplementary Fig. 1. The species distribution of the result of NR annotation.

Additional file 2: Supplementary Fig. 2. KOG function classification of consensus sequences of all the transcripts detected in RNA-Seq of Scylla paramamosain megalopa under different levels of salinities.

Additional file 3: Supplementary Fig. 3. Gene ontology (GO) assignment of assembled transcripts of Scylla paramamosain megalopa.

Additional file 4: Supplementary Table 1. Primers used for qRT-PCR. Supplementary Table 2. Summary of RNA sequencing of the Scylla paramamosain megalopa under different salinities. Supplementary Table 3. Differentially expressed genes in the comparison of low salinity (LS) and control salinity (CS) in Scylla paramamosain megalopa. Supplementary Table 4. Differentially expressed genes in the comparison of high salinity (HS) and control salinity (CS) in Scylla paramamosain megalopa.

\section{Acknowledgements}

We would like to thank Feng Lin for the instruction and assistance in the culture of mud crab.

\section{Authors' contributions}

$\mathrm{HM}$ and QW conceptualized the experiment. YZ, WQ and SF collected the specimens. $Y Z$ and $Q W$ performed the experiment. $Y Z$ analyzed the data and prepared the required figures. $Y Z$ wrote the manuscript. HM, SL, HZ, YZ and $\mathrm{MI}$ revised the manuscript and contributed to additional discussion. All authors read and approved the final manuscript.

\section{Funding}

This study was funded by the Program of Agricultural and Rural Department of Guangdong Province (Yuenong2019B4), the National Program for Support of Top-Notch Young Professionals, the Science and Technology Project of Guangdong Province (2018A050506080), the Shantou University Scientific Research Foundation for Talents (No. NTF17006), the "Sail Plan" Program for the Introduction of Outstanding Talents of Guangdong Province, China, the Malaysia's Ministry of Higher Education under Niche Research Grant Scheme (NRGS) (Vot. No. 53131), and the Program for Innovation and Enhancement of School of Department of Education of Guangdong Province (No. 2017KCXTD014)

\section{Availability of data and materials}

The datasets generated during the current study were deposited in the National Center for Biotechnology Information (NCBI) Sequence Read Archive (SRA, http://www.ncbi.nlm.nih.gov/Traces/sra) with the accession numbers SRR10493620, SRR10493619 and SRR10493618 corresponding to the LS, CS and HS group, respectively. 


\section{Ethics approval and consent to participate}

The collection of cultured crabs was permitted by the animal owners who agreed to be involved in the project through their respective associations with Marine Biology Institute of Shantou University. All experiments were conducted with strict accordance with the recommendations in the Guide for the Care and use of Laboratory Animals of Shantou University and approval of the Institutional Animal Care and Use Ethics Committee of Shantou University. The methods applied in this study were carried out strictly following the Laboratory Animal Management Principles of China.

\section{Consent for publication}

Not applicable.

\section{Competing interests}

The authors declare that they have no competing interests.

\section{Author details}

${ }^{1}$ Guangdong Provincial Key Laboratory of Marine Biotechnology, Institute of Marine Sciences, Shantou University, 243 Daxue Road, Shantou 515063, China. ${ }^{2}$ STU-UMT Joint Shellfish Research Laboratory, Shantou University, Shantou 515063, China. ${ }^{3}$ Institute of Tropical Aquaculture, Universiti Malaysia Terengganu, 21030 Kuala Terengganu, Malaysia.

Received: 30 June 2020 Accepted: 30 July 2020

Published online: 14 August 2020

\section{References}

1. Ahmad KA, Wang G, Unger G, Slaton J, Ahmed K. Protein kinase CK2 - a key suppressor of apoptosis. Adv Enzym Regul. 2008;48:179-87.

2. Alberto GS, Encarnación L, Alejandro ZR. Evolutionary history of $\mathrm{Na}, \mathrm{K}$ ATPases and their osmoregulatory role. Genetica. 2009;136:479-90.

3. Anger K, Riesebeck K, Püschel C. Effects of salinity on larval and early juvenile growth of an extremely euryhaline crab species, Armases miersii (Decapoda: Grapsidae). Hydrobiologia. 2000;426(1):161-8.

4. Araki N. Role of microtubules and myosins in Fc gamma receptor-mediated phagocytosis. Front Biosci. 2006;11:1479-90.

5. Arunachalam B, Phan UT, Geuze HJ, Cresswell P. Enzymatic reduction of disulfide bonds in lysosomes: characterization of a gamma-interferoninducible lysosomal thiol reductase (GILT). Proc Natl Acad Sci U S A. 2000; 97(2):745-50.

6. Barman HK, Patra SK, Das V, Mohapatra SD, Jayasankar P, Mohapatra C, Mohanta R, Panda RP, Rath SN. Identification and characterization of differentially expressed transcripts in the gills of freshwater prawn (Macrobrachium rosenbergii) under salt stress. Sci World J. 2012;2012:1-11.

7. Bellelli A, Giardina B, Corda M, Pellegrini MG, Cau A, Condo's G, Brunori M. Sexual and seasonal variability of lobster hemocyanin. Comp Biochem Physiol A. 1988;91(3):445-9.

8. Bruntz RC, Lindsley CW, Brown HA. Phospholipase D signaling pathways and phosphatidic acid as therapeutic targets in cancer. Pharmacol Rev. 2014;66(4):1033-79.

9. Chand BK, Trivedi RK, Dubey SK, Rout SK, Beg MM, Das UK. Effect of salinity on survival and growth of giant freshwater prawn Macrobrachium rosenbergii (de Man). Aquac Rep. 2015;2:26-33.

10. Chen JC, Chia PG. Osmotic and ionic concentrations of Scylla serrata (Forskål) subjected to different salinity levels. Comp Biochem Physiol A. 1997;117(2):239-44.

11. Chen K, Li E, Li T, Xu C, Wang X, Lin H, Qin JG, Chen L. Transcriptome and molecular pathway analysis of the hepatopancreas in the Pacific white shrimp Litopenaeus vannamei under chronic low-salinity stress. PLoS One. 2015;10(7):e0131503.

12. Chen X, Lin Q, Wang G, Li S, Ye H. Feeding in the megalopae of the mud crab (Scylla paramamosain): mechanisms, plasticity, role of chelipeds and effect of prey density. Mar Freshw Behav Phy. 2013;46(5):321-36.

13. Chung KF, Lin HC. Osmoregulation and Na,K-ATPase expression in osmoregulatory organs of Scylla paramamosain. Comp Biochem Physiol A. 2006;144(1):48-57.

14. Cole GB, Keum G, Liu J, Small GW, Satyamurthy N, Kepe V, Barrio JR. Specific estrogen sulfotransferase (SULT1E1) substrates and molecular imaging probe candidates. Proc Natl Acad Sci U S A. 2010;107:6222-7.

15. Collins JF. Novel insights into intestinal and renal folate transport. Focus on 'Apical membrane targeting and trafficking of the human proton-coupled folate transporter in polarized epithelia'. Am J Physiol-Cell Ph. 2008;294: C381-2.

16. Dawson RJ, Locher KP. Structure of a bacterial multidrug $A B C$ transporter. Nature. 2006:443:180-5.

17. De la Vega E, Degnan BM, Hall MR, Wilson KJ. Differential expression of immune-related genes and transposable elements in black tiger shrimp (Penaeus monodon) exposed to a range of environmental stressors. Fish Shellfish Immun. 2007;23(5):1072-88.

18. Decker $\mathrm{H}$, Jaenicke $\mathrm{E}$. Recent findings on phenoloxidase activity and antimicrobial activity of hemocyanins. Dev Comp Immunol. 2004;28(7-8): 673-87.

19. DeHart AK, Schnell JD, Allen DA, Hicke L. The conserved Pkh-Ypk kinase cascade is required for endocytosis in yeast. J Cell Biol. 2002;156:241-8.

20. Derrien M, van Passel MW, van de Bovenkamp JH, Schipper R, de Vos W, Dekker J. Mucin bacterial interactions in the human oral cavity and digestive tract. Gut Microbes. 2010;1(4):254-68.

21. Díaz-Nido J, Serrano L, Méndez E, Avila J. A casein kinase ii-related activity is involved in phosphorylation of microtubule-associated protein MAP-1B during neuroblastoma cell differentiation. J Cell Biol. 1988;106:2057-65.

22. Fiol DF, Kultz D. Osmotic stress sensing and signaling in fishes. FEBS J. 2007; 274:5790-8.

23. Friant S, Zanolari B, Riezman H. Increased protein kinase or decreased PP2A activity bypasses sphingoid base requirement in endocytosis. EMBO J. 2000; 19:2834-44.

24. Fullerton MD, Wagner L, Yuan Z, Bakovic M. Impaired trafficking of choline transporter-like protein-1 at plasma membrane and inhibition of choline transport in THP-1 monocyte-derived macrophages. Am J Physiol Cell Physiol. 2006;290:C1230-8.

25. Gagnon E, Forbush B, Caron L, Isenring P. Functional comparison of renal Na-K-Cl cotransporters between distant species. Am J Physiol Cell Physiol. 2002;284:365-70.

26. Gamba G. Molecular physiology and pathophysiology of electroneutral cation-chloride cotransporters. Physiol Rev. 2005;85:423-93.

27. Gao W, Tan B, Mai K, Chi S, Liu H, Dong X, Yang Q. Profiling of differentially expressed genes in hepatopancreas of white shrimp (Litopenaeus vannamei) exposed to long-term low salinity stress. Aquaculture. 2012;364:186-91.

28. Genard B, Pernet F, Lemarchand K, Boudry P, Moraga D, Tremblay R. Physiological and biochemical changes associated with massive mortality events occurring in larvae of American oyster (Crassostrea virginica). Aquat Living Resour. 2011;24:267-360.

29. Goodman A, Goode BL, Matsudaira P, Fink GR. The saccharomyces cerevisiae calponin/transgelin homolog scp1 functions with fimbrin to regulate stability and organization of the actin cytoskeleton. Mol Biol Cell. 2003:14:2617-29.

30. Goodsell DS. The molecular perspective: estrogen sulfotransferase. Oncologist. 2006;11:418-9.

31. Grigoriev VG, Thweatt R, Moerman EJ, Goldstein S. Expression of senescenceinduced protein WS3-10 in vivo and in vitro. Exp Gerontol. 1996;31:145-57.

32. Gründer S, Thiemann A, Pusch M, Jentsch TJ. Regions involved in the opening of CIC-2 chloride channel by voltage and cell volume. Nature. 1992;360(6406):759.

33. Guerra B, Issinger OG. Protein kinase CK2 and its role in cellular proliferation, development and pathology. Electrophoresis. 1999;20(2):391-408.

34. Harvey SH, Krien MJE, O'Connell MJ. Structural maintenance of chromosomes (SMC) proteins, a family of conserved ATPases. Genome Biol. 2002;3(2):3003.

35. Havird JC, Henry RP, Wilson AE. Altered expression of $\mathrm{Na}^{+} / \mathrm{K}^{+}$-ATPase and other osmoregulatory genes in the gills of euryhaline animals in response to salinity transfer: a meta-analysis of 59 quantitative PCR studies over 10 years. Comp Biochem Physiol D. 2013;8:131-40.

36. Havird JC, Santos SR, Henry RP. Osmoregulation in the Hawaiian anchialine shrimp Halocaridina rubra (Crustacea: Atyidae): expression of ion transporters, mitochondria-rich cell proliferation and hemolymph osmolality during salinity transfers. J Exp Biol. 2014;217:2309-20.

37. Henry RP, Garrelts EE, McCarty MM, Towle DW. Differential induction of branchial carbonic anhydrase and $\mathrm{Na}^{+} / \mathrm{K}^{+}$ATPase activity in the euryhaline crab, Carcinus maenas, in response to low salinity exposure. J Exp Zool. 2002;292(7):595-603.

38. Henry RP, Gehnrich S, Weihrauch D, Towle DW. Salinity-mediated carbonic anhydrase induction in the gills of the euryhaline green crab, Carcinus maenas. Comp Biochem Physiol A. 2003;136(2):243-58. 
39. Henry RP, Thomason KL, Towle DW. Quantitative changes in branchial carbonic anhydrase activity and expression in the euryhaline green crab, Carcinus maenas, in response to low salinity exposure. J Exp Zool A. 2006; 305(10):842-50.

40. Hill BJ. Offshore spawning by the Portunid Crab Scylla serrata (Crustacea, Decapoda). Mar Biol. 1994;120:379-84.

41. Hollenstein K, Frei DC, Locher KP. Structure of an ABC transporter in complex with its binding protein. Nature. 2007;446:213-6.

42. Hui M, Liu Y, Song C, Li Y, Shi G, Cui Z. Transcriptome changes in Eriocheir sinensis megalopae after desalination provide insights into osmoregulation and stress adaption in larvae. PLoS One. 2014;9(12):e114187.

43. Kanehisa M, Araki M, Goto S, Hattori M, Hirakawa M, Itoh M, Katayama T, Kawashima S, Okuda S, Tokimatsu T, Yamanishi Y. KEGG for linking genomes to life and the environment. Nucleic Acids Res. 2007;36(suppl_1):D480-4.

44. Keenan CP. Aquaculture of mud crab, genus Scylla past, present and future. In: Keenan CP, Blackshaw A, editors. Mud crab aquaculture and biology. ACIAR proceedings, vol. 78. Canberra: ACIAR; 1999. p. 9-13.

45. Kikawada T, Saito A, Kanamori Y, Nakahara Y, Iwata K, Tanaka D, Watanabe M, Okuda T. Trehalose transporter 1, a facilitated and high-capacity trehalose transporter, allows exogenous trehalose uptake into cells. Proc Natl Acad Sci U S A. 2007;104(28):11585-90.

46. Kim D, Langmead B, Salzberg SL. HISAT: a fast spliced aligner with low memory requirements. Nat Methods. 2015;12(4):357-60.

47. Knight PJ, Crickmore N, Ellar DJ. The receptor for Bacillus thuringiensis CrylA (c) delta-endotoxin in the brush border membrane of the lepidopteran Manduca sexta is aminopeptidase N. Mol Microbiol. 1994;11:429-36.

48. Kolesnick R. The therapeutic potential of modulating the ceramide/ sphingomyelin pathway. J Clin Invest. 2002;110(1):3-8.

49. Larsen PF, Nielsen EE, Koed A, Thomsen DS, Olsvik PA, Loeschcke V. Interpopulation differences in expression of candidate genes for salinity tolerance in winter migrating anadromous brown trout (Salmo trutta L.) BMC Genet. 2008:9:12.

50. Le Vay L, Ut VN, Walton M. Population ecology of the mud crab Scylla paramamosain (Estampador) in an estuarine mangrove system; a markrecapture study. Mar Biol. 2007;151(3):1127-35.

51. Lee $S Y$, Lee BL, Söderhäll K. Processing of an antibacterial peptide from hemocyanin of the freshwater crayfish Pacifastacus leniusculus. J Biol Chem. 2003;278:7927-33.

52. Lee SY, Lee BL, Söderhäll K. Processing of crayfish hemocyanin subunits into phenoloxidase. Biochem Biophys Res Commun. 2004;322:490-6.

53. Leier I, Jedlitschky G, Buchholz U, Center MS, Cole SP, Deeley RG, Keppler D. ATP-dependent glutathione disulphide transport mediated by the MRP gene-encoded conjugate export pump. Biochem J. 1996;314:433-7.

54. Li E, Wang S, Li C, Wang X, Chen K, Chen L. Transcriptome sequencing revealed the genes and pathways involved in salinity stress of Chinese mitten crab, Eriocheir sinensis. Physiol Genomics. 2014;46:177-90.

55. Li YY, Ai CX, Liu LJ. Mud crab, Scylla paramamosain China's leading maricultured crab. In: Gui JF, Tang QS, Li ZJ, Liu JS, De Silva SS, editors. Aquaculture in China: success stories and modern trends. Hoboken: Wiley; 2018. p. 226-33.

56. Liu S, Li Q, Liu Z. Genome-wide identification, characterization and phylogenetic analysis of 50 catfish ATP-binding cassette (ABC) transporter genes. PLoS One. 2013;8(5):e63895.

57. Luquet CM, Weihrauch D, Senek M, Towle DW. Induction of branchial ion transporter mRNA expression during acclimation to salinity change in the euryhaline crab Chasmagnathus granulatus. J Exp Biol. 2005;208:3627-36.

58. Misbah I, Karim MY, Aslamyah S. Effect of salinity on the survival of mangrove crab Scylla tranquebarica larvae at zoea-megalopa stages. AACL Bioflux. 2017;10(6):1590-5.

59. Nakanishi K, Yaoi K, Nagino Y, Hara H, Kitami M, Atsumi S, Miura N, Sato R. Aminopeptidase $\mathrm{N}$ isoforms from the midgut of Bombyx mori and Plutella xylostella-their classification and the factors that determine their binding specificity to Bacillus thuringiensis Cry1A toxin. FEBS Lett. 2002;519:215-20.

60. Nurdiani R, Zeng C. Effects of temperature and salinity on the survival and development of mud crab, Scylla serrata (Forsskål), larvae. Aquac Res. 2007; 38(14):1529-38.

61. O'Regan S, Traiffort E, Ruat M, Cha N, Compaore D, Meunier FM. An electric lobe suppressor for a yeast choline transport mutation belongs to a new family of transporter-like proteins. Proc Natl Acad Sci U S A. 2000;97:1835-40.

62. Orozco H, Matallana E, Aranda A. Oxidative stress tolerance, adenylate cyclase, and autophagy are key players in the chronological life span of
Saccharomyces cerevisiae during winemaking. Appl Environ Microbiol. 2012; 78(8):2748-57.

63. Pandit A, Rai V, Bal S, Sinha S, Kumar V, Chauhan M, Gautam RK, Singh R, Sharma PC, Singh AK, Gaikwad K, Sharma TR, Mohapatra T, Singh NK. Combining QTL mapping and transcriptome profiling of bulked RILs for identification of functional polymorphism for salt tolerance genes in rice (Oriza sativa L.). Mol Genet Genomics. 2010;284:121-36.

64. Parado-Estepa FD, Quinitio ET. Influence of salinity on survival and molting in early stages of three species of Scylla crabs. Isr J Aquacult Bamidgeh. 2011;63:1-6.

65. Parenrengi A. Crablet of mangrove crab, Scylla olivacea rearing at the different salinity regimes. J Aquac Res Dev. 2014;5:255.

66. Park K, Kwak IS. Expression of stress response HSP70 gene in Asian paddle crabs, Charybdis japonica, exposure to endocrine disrupting chemicals, bisphenol A (BPA) and 4-nonylphenol (NP). Ocean Sci J. 2013;48(2):207-14.

67. Péqueux A. Osmotic regulation in crustaceans. J Crustac Biol. 1995;15(1):1-60.

68. Qiu A, Jansen M, Sakaris A, Min SH, Chattopadhyay S, Tsai E, Sandoval C, Zhao R, Akabas MH, Goldman ID. Identification of an intestinal folate transporter and the molecular basis for hereditary folate malabsorption. Cell. 2006;127:917-28.

69. Rajagopal R, Sivakumar S, Agrawal N, Malhotra P, Bhatnagar RK. Silencing of midgut aminopeptidase $\mathrm{N}$ of Spodoptera litura by double-stranded RNA establishes its role as Bacillus thuringiensis toxin receptor. J Biol Chem. 2002; 277:46849-51.

70. Remelli W, Cereda A, Papenbrock J, Forlani F, Pagani S. The rhodanese RhdA helps Azotobacter vinelandii in maintaining cellular redox balance. Biol Chem. 2010;391(7):777-84.

71. Romano $\mathrm{N}$, Zeng C. Importance of balanced $\mathrm{Na}^{+} / \mathrm{K}^{+}$ratios for blue swimmer crabs, Portunus pelagicus, to cope with elevated ammonia- $\mathrm{N}$ and differences between in vitro and in vivo gill $\mathrm{Na}^{+} / \mathrm{K}^{+}$-ATPase responses. Aquaculture. 2011;318(1-2):154-61.

72. Romano N, Zeng CS. Osmoregulation in decapod crustaceans: implications to aquaculture productivity, methods for potential improvement and interactions with elevated ammonia exposure. Aquaculture. 2012;334:12-23.

73. Sang HM, Fotedar R. Growth, survival, haemolymph osmolality and organosomatic indices of the western king prawn (Penaeus latisulcatus Kishinouye, 1896) reared at different salinities. Aquaculture. 2004;234(1-4):601-14.

74. Scavia D, Field JC, Boesch DF, Buddemeier RW, Burkett V, Cayan DR, Fogarty M, Harwell MA, Howarth RW, Mason C, Reed DJ, Royer TC, Sallenger AH, Titu JG. Climate change impacts on U.S. coastal and marine ecosystems. Estuaries. 2002;25(2):149-64.

75. Sun C, Zhang S. Immune-relevant and antioxidant activities of vitellogenin and yolk proteins in fish. Nutrients. 2015;7(10):8818-29.

76. Tang T, Ji C, Yang Z, Liu F, Xie S. Involvement of the Macrobrachium nipponense rhodanese homologue $2, \mathrm{MnRDH} 2$ in innate immunity and antioxidant defense. Fish Shellfish Immunol. 2017;70:327-34.

77. Teranishi KS, Stillman JH. A cDNA microarray analysis of the response to heat stress in hepatopancreas tissue of the porcelain crab Petrolisthes cinctipes. Comp Biochem Physiol D. 2007;2:53-62.

78. Thiemann A, Gründer S, Pusch M, Jentsch TJ. A chloride channel widely expressed in epithelial and non-epithelial cells. Nature. 1992;356(6364):57.

79. Towle DW, Henry RP, Terwilliger NB. Microarray-detected changes in gene expression in gills of green crabs (Carcinus maenas) upon dilution of environmental salinity. Comp Biochem Physiol D. 2011;6:115-25.

80. Trachootham D, Lu W, Ogasawara MA, Valle NR-D, Huang P. Redox regulation of cell survival. Antioxid Redox Signal. 2008;10:1343-74.

81. Vigoreaux JO, Moore JR, Maughan DW. Role of the elastic protein projectin in stretch activation and work output of Drosophila flight muscles. In: Granzier HL, Pollack GH, editors. Elastic filaments of the cell. Advances in experimental medicine and biology, vol. 481. Boston: Springer; 2000.

82. Waiho K, Fazhan H, Quinitio ET, Baylon JC, Fujaya Y, Azmie G, Wu Q, Shi X, Ikhwanuddin M, Ma H. Larval rearing of mud crab (Scylla): what lies ahead. Aquaculture. 2018;493:37-50.

83. Walton ME, Le Vay L, Le Minh T, Ut VN. Significance of mangrove-mudflat boundaries as nursery grounds for the mud crab, Scylla paramamosain. Mar Biol. 2006;149:1199-207.

84. Wauben IPM, Wainwright PE. The influence of neonatal nutrition on behavioral development: a critical appraisal. Nutr Rev. 1999;57:35-44.

85. Wei C, Luqing P, Zhang X, Xu L, Si L, Tong R, Wang H. Transcriptome analysis of hemocytes from the white shrimp Litopenaeus vannamei with the injection of dopamine. Fish Shellfish Immunol. 2019;94:497-509. 
86. Wen G, Kühne H, Rauer C, Ringseis R, Eder K. Mouse g-butyrobetaine dioxygenase is regulated by peroxisome proliferator-activated receptor a through a PPRE located in the proximal promoter. Biochem Pharmacol. 2011:82:175-83.

87. Wu B, Liu Z, Zhou L, Ji G, Yang A. Molecular cloning, expression, purification and characterization of vitellogenin in scallop Patinopecten yessoensis with special emphasis on its antibacterial activity. Dev Comp Immunol. 2015;49: 249-58.

88. Wu Q, Waiho K, Huang Z, Li S, Zheng H, Zhang Y, Ikhwanuddin M, Lin F, Ma H. Growth traits and biochemical composition dynamics of ovary, hepatopancreas and muscle tissues at different ovarian maturation stages of female mud crab, Scylla paramamosain. Aquaculture. 2020;515:734560.

89. Xie C, Mao X, Huang J, Ding Y, Wu J, Dong S, Kong L, Gao G, Li CY, Wei L. KOBAS 2.0: a web server for annotation and identification of enriched pathways and diseases. Nucleic Acids Res. 2011;39(suppl 2):W316-22.

90. Xu Q, Liu Y. Gene expression profiles of the swimming crab Portunus trituberculatus exposed to salinity stress. Mar Biol. 2011;158(10):2161-72.

91. Yang F, Xu HT, Dai ZM, Yang WJ. Molecular characterization and expression analysis of vitellogenin in the marine crab Portunus trituberculatus. Comp Biochem Physiol B. 2005;142(4):456-64.

92. Young MD, Wakefield MJ, Smyth GK, Oshlack A. Gene ontology analysis for RNA-seq: accounting for selection bias. Genome Biol. 2010;11(2):R14.

93. Zaman GJR, Lankelma J, Vantellingen O, Beijnen JH, Dekker H, Paulusma CC, Oude Elferink RPJ, Baas F, Borst P. Role of glutathione in the export of compounds from cells by the multidrug-resistance-associated protein. Proc Natl Acad Sci U S A. 1995:92:7690-4.

94. Zhang S, Sun Y, Pang Q, Shi X. Hemagglutinating and antibacterial activities of vitellogenin. Fish Shellfish Immunol. 2005;19:93-5.

95. Zhen JT, Shao YF. Experimental study on thermal environment in overwintering greenhouse for Scylla serrate. J Zhejiang Ocean Univ (in Chinese). 2001;20:205-8.

\section{Publisher's Note}

Springer Nature remains neutral with regard to jurisdictional claims in published maps and institutional affiliations.

Ready to submit your research? Choose BMC and benefit from:

- fast, convenient online submission

- thorough peer review by experienced researchers in your field

- rapid publication on acceptance

- support for research data, including large and complex data types

- gold Open Access which fosters wider collaboration and increased citations

- maximum visibility for your research: over $100 \mathrm{M}$ website views per year

At $\mathrm{BMC}$, research is always in progress.

Learn more biomedcentral.com/submissions 